УДК 342

DOI https://doi.org/10.32837/pyuv.v0i1.737

\author{
А. Л. Харченко \\ orcid.org/0000-0003-4499-5065 \\ студентка IV курсу \\ Навчально-наукового інститута права \\ Сулського державного університету \\ М. С. Уткіна \\ orcid.org/0000-0002-3801-3742 \\ кандидат юридичних наук, \\ старший викладач кафедри кримінально-правових дисциплін та судочинства \\ Навчально-наукового інститута права \\ Сумського державного університету
}

\title{
ЩОДО ЕЛЕКТРОННИХ ПОСЛУГ В УКРАЇНІ: ЮРИДИЧНА ПРИРОДА, ОЗНАКИ ТА ПРИНЦИПИ
}

Стрімкий розвиток і розповсюдження нових інформаційно-телекомунікаційних технологій несе з собою кардинальні зміни в контексті діяльності інформаційної сфери на світовому рівні. Такий вплив має безпосередній зв'язок із державою, державними структурами та суспільством загалом, стосується економічної і соціальної сфер, науки і освіти, культури і способу життя людей. Розвиток інформаційно-телекомунікаційних технологій $е$ важливим «імпульсом» для становлення світової економіки. Нововведення, які нині мають місце у сфері розвитку інформаційних технологій, сприяють новим економічним, соціально-культурним і політичним відносинам в суспільному житті, це так зване «глобальне інформаційне суспільство». Інформаційне суспільство розглядається як такий стан розвитку суспільства, що характеризується високорозвиненою інформаційною культурою, інфраструктурою i масовою інформатизацією, широким доступом населення до інформаційних та електронних ресурсів, наявністю ринку інформаційних продуктів і пріоритетним розвитком інформаційного сектору економіки.

Одним із таких факторів розвитку слід визначити появу, закріплення та урегулювання на законодавчому рівні електронних довірчих послуг. Формування системи надання такого виду послуг спрямовано насамперед на створення ефективного інформаційно-правового механізму реалізації прав людини і громадянина в контексті глобалізаційних процесів. Зважаючи на це, основним принципом надання електронних довірчих послуг є їх доступність для кожного суб'єкта суспільних відносин, незважаючи на момент та місце.

$\mathrm{У}$ цей період розвитку наукової думки є низка теоретичних підходів щодо трактування категоpiї «електронні послуги». 3 метою об'єктивного розуміння категорії «електронні послуги» вважаємо за доцільне окремо надати визначення категорії, яка є її складником, - «послуга». Це зумовлено тим, що остання категорія є базисом для розуміння сутності категорії «електронні послуги» загалом. Зокрема, з метою визначення загального необхідно насамперед визначити окреме.

Згідно з Ю. Тищенко, термін «послуга» необхідно розглядати як дію, роботу, операцію, результат господарської діяльності, комплекс заходів щодо надання отримувачу послуги, певного необхідного для нього блага, яке він може спожити під час отримання послуги (транспорті послуги, побутове, медичне обслуговування) і використовувати іï результати в майбутньому (консультаційні, інформаційні послуги тощо) [1, с. 95]. Ф. Котлер акцентує увагу на тому, що послуга є будь-якою діяльністю, що являє собою благо, яке може бути запропоноване однією стороною іншій, а за своєю суттю вона $є$ невідчутною і не приводить до заволодіння власністю (до передачі власності) [2, с. 818].

Проте неможливо не зупинитися на підході, який простежується в нормативно-правовій базі, а саме в кодифікованому акті - Цивільному кодексі України. Зокрема, Глава 63 має назву «Послуги. Загальні положення», зміст іiі може застосовуватися до усіх договорів щодо надання послуг, у разі, що це не суперечить суті зобов'язання. Зокрема, відповідно до статті 901 Цивільного кодексу України, за договором про надання послуг одна сторона (виконавець) зобов' язується за завданням другої сторони (замовника) надати послугу, яка споживається у процесі вчинення певної дії або здійснення певної діяльності, а замовник зобов'язується оплатити виконавцеві зазначену послугу, якщо інше не встановлено договором [3]. Зважаючи на це, пропонуємо під послугою розуміти діяльність щодо надання однією стороною іншій певного блага, що має користь для цієї сторони, задовольняє її потреби та може здійснюватися за ініціативою особи або ж на її прохання.

Надаючи визначення категорії «електронна послуга», звертаємося до законодавчої бази, що урегульовує це питання. Зокрема, Закон України «Про електронні довірчі послуги» [4] визначає 
«електронну послугу» як будь-яку послугу, що надається через інформаційно-телекомунікаційну систему. Також визначення електронних державних послуг знаходимо у Модельному законі про електронні державні послуги [5]. Відповідно до нього, електронні державні послуги необхідно розуміти як державну послугу, що надається інформаційно-комунікаційною мережею з використанням інформаційних технологій.

Щодо доктринальних джерел, то тут превалює декілька визначень цієї категорії. Зокрема, О. Смельяненко пропонує під поняттям «електронні послуги» розуміти надання в електронній формі урядової інформації: програм і напрямів діяльності уряду, формування стратегій задля розв'язання найважливіших суспільних проблем. Електронні послуги характеризуються новими формами громадянської участі та співробітництва між владою і громадянами [6]. За С. Вишняковою, під «електронними послугами» слід розуміти різні види матеріальних і нематеріальних послуг, що надаються в електронній формі з використанням інформаційно-комунікаційних технологій, включаючи Інтернет» [7, с. 17]. Таким чином, аналізуючи поняття "електронні послуги», констатуємо, що його зміст тісно пов'язаний із використанням інформаційно-комунікаційних технологій.

У контексті реформ, що мають місце в Україні, необхідно наголосити на тому, що одним із напрямів діяльності Уряду є створення цифрової держави шляхом цифровізації послуг. Зважаючи на вищенаведені трактування категорії «електронні послуги», можемо виокремити основні ознаки їх реалізації, зокрема:

- надання такого роду послуг за ініціативою, заявою фізичних та юридичних осіб за наявності електронного підпису, сертифікатів акредитованих центрів, сертифікації ключів;

- надання незалежно від форми їх вираження (усна чи письмова);

- надання незалежно від порядку отримання їі органом влади;

- регламентація на законодавчому рівні отримання електронних послуг (здійснення електронної послуги відбувається у разі наявності спеціальної правової норми, що регулює порядок надання такої послуги. Вимога особи до владного органу вчинення певних дій на її користь може розглядатися як електронна послуга лише за умови чіткої регламентації порядку розгляду цієї заяви). Зважаючи на це, вимагати надання електронної послуги, надання якої не передбачено законом, від певного державного органу неможливо;

- встановлена кінцева форма індивідуального адміністративного акта, у якому вказано його адресат.

Представники наукової спільноти, розглядаючи питання принципів права, констатують, що вони як основа закріплені в Конституцій України. Зокрема, до таких принципів науковці відносять: 1) принцип пріоритету прав і свобод людини та громадянина; 2) принцип верховенства права та правового закону; 3) принцип рівності однорідних суб'єктів адміністративного права перед законом; 4) принцип демократизму; 5) принцип взаємної відповідальності суб'єктів публічної адміністрації і об'єктів публічного управління; 6) принцип гуманізму і справедливості у відносинах між суб'єктами публічної адміністрації та об'єктами публічного управління [8, с. 82]. Загалом принципи є керівними засадами, базисом будь-якої системи, які можуть змінюватися під впливом змін, що мають місце у суспільстві.

Аналізуючи принципи надання електронних послуг, слід визначити, що стаття 4 Закону України «Про адміністративні послуги» [9] містить перелік загальних принципів надання електронних послуг. Цей закон розглядається у зв'язку із тим, що принципи надання електронних послуг становлять собою сукупність міжгалузевих принципів, зокрема правової та управлінських сфер.

Відповідно до вищезазначеного Закону, до загальних принципів належать принципи: 1) верховенства права, у тому числі законності та юридичної визначеності; 2) стабільності; 3) рівності перед законом; 4) відкритості та прозорості; 5) оперативності та своєчасності; 6) доступності інформації про надання електронних послуг; 7) захищеності персональних даних; 8) раціональної мінімізації кількості документів та процедурних дій, що вимагаються для отримання електронних послуг; 9) неупередженості та справедливості; 10) доступності та зручності для суб'єктів звернень [9]. Констатуємо, що ці принципи певним чином дублюють ті, що визначені в Основному законі Україні.

Спеціальні принципи надання електронних послуг мають бути спрямовані на досягнення таких фундаментальних цілей, як підтримка балансу між інтересами держави й інтересами скаржників та підвищення довіри таких органів до діяльності адміністративних та державних органів влади. Зокрема, А. Ішханян до таких принципів відніс принципи: безперервності, результативності, професійності, відповідальності; єдності, підпорядкованості; територіально-галузевий та зонально-предметний; своєчасності, зручності, доступності, мовчазної згоди [10, с. 43].

Говорячи про критерії класифікації надання електронних послуг, можна виокремити такі: а) суб'єкт-споживач - фізичні особи; юридичні особи; змішані, тобто споживачами можуть бути як фізичні, так і юридичні особи; б) суб'єкт надання - державні; муніципальні органи; в) зміст та обсяг процедурних дій - основні послуги, супутні послуги, додаткові послуги; г) юридичні наслідки - правонаділяючого, правоприпиняючого, 
правообмежуючого характеру; д) термін надання - короткострокові; довгострокові; е) платність - платні (за надання яких стягується державне мито), безоплатні (державне мито не стягується); ж) результат видачі адміністративного акта - дозвіл, ліцензія, свідоцтво, посвідчення, посвідка, реєстрація, довідка, рішення.

Пропонуємо таку класифікацію електронних послуг за видами електронного подання, за сферою діяльності, за суб’єктом видання, за споживачами, за місцем отримання 3 погляду клієнта та 3 тпогляду залучення в електронний сервіс.

\section{1. За видами електронного подання.}

Згідно 3 «Порядком надання інформаційних та інших послуг з використанням електронної інформаційної системи «Електронний Уряд» розрізняються чотири види електронного подання інформаційної послуги:

- інформування (надання безпосередньо інформації про державні (адміністративні) послуги);

- одностороння взаємодія (забезпечена можливість користувачу отримати електронну форму документа);

- двостороння взаємодія (забезпечена можливість обробки електронної форми документа, включаючи ідентифікацію);

- проведення трансакцій (електронна реалізація можливостей прийняття рішень та їх доставка).

3 технологічного погляду, надання послуг першого і другого виду в наш час повністю вирішені, а надання послуг третього та четвертого виду (які потребують ідентифікації сторін електронної взаємодії і пов'язані з використанням електронного цифрового підпису) потребують свого розв' язання.

2. За сферою діяльності електронні послуги поділяються на:

- послуги інформаційного характеру;

- послуги консультаційного характеру;

- послуги з підготовки політичних рішень або законів;

- послуги із взаємодії між установами та організаціями;

- послуги з надання допомоги та сприяння;

- послуги обслуговування державного замовлення;

- послуги 3 реалізації функцій нагляду та контролю з боку державних відомств.

Сферу діяльності можна розділити за ступенем новизни діяльності в процесі надання електронних послуг на новий вид діяльності, реорганізацію або реінжиніринг існуючих послуг.

3. За суб'єктом видання послуги поділяються на ті, які надаються ЦОВВ та їх підприємствами, місцевими органами державної влади, органами місцевого самоврядування та бізнесорганізаціями.
4. За споживачами різняться на послуги для публічних органів влади, громадян та бізнесових організацій:

- B2B (Business-to-Business, Бізнес-бізнес) передбачає насамперед різні способи електронної взаємодії між бізнесовими організаціями;

- B2C (Business-to-Citizens, Бізнес-громадянин) характеризується тим, що споживачем послуги є приватна особа, яка, наприклад, здійснює купівлю товарів та послуг через Інтернет;

- G2B (Government-to-Business, Уряд-бізнес) обслуговування державного замовлення. У G2B входять всі відносини між бізнесовими організаціями та державними установами. Наприклад, інформація про можливі закупки органами влади публікується в Інтернеті, а компанії можуть взяти участь у тендері електронним способом. Нині цей вид електронних послуг в Україні знаходиться у зародковому стані, але має перспективи розвитку за умови, що органи влади використають свої можливості для підтримки та розвитку електронної комерції;

- G2C (Government-to-Citizens, Уряд-громадяни) - різні види адміністративних послуг в електронному вигляді населенню;

- G2G (Government-to-Government, Уряд-уряд) - обмін даними через електронні обмінники між урядовими авторами. Це включає в себе внутрішні та міжвідомчі обміни на національному рівні, так само, як обмін між національними, регіональними та локальними рівнями;

- C2C (Citizens-to-Citizens, Громадянин-громадянин) - електронні аукціони, дошки оголошень тощо.

5. За місцем отримання з погляду клієнта поділяються на: державний орган; «єдине вікно»; портал органу влади.

6. 3 погляду залучення в електронний сервіс повністю автоматизовані та автоматизовані частково:

- повністю автоматизовані - послуги, в яких відповідні процеси (прийняття заяв, надання послуги, оплата, доставка тощо) виконуються в електронній формі; особистий контакт та участь людини (державних службовців) під час надання таких послуг мінімізовані або зовсім відсутні;

- автоматизовані частково - послуги, в яких частина процесів виконується в електронному вигляді, а частина - вручну.

Щодо вироблення критеріїв якості електронних послуг, то ними можуть слугувати критерії, які визначені в Концепції розвитку системи надання адміністративних послуг органами влади, «які повинні слугувати взірцем для адміністративних послуг в електронному вигляді» [11, с. 18].

Такими критеріями, згідно з Концепцією, є:

- результативність - задоволення потреби фізичної або юридичної особи в адміністративній послузі; 
- своєчасність - надання адміністративної послуги в установлений законом строк;

- доступність - фактична можливість фізичних та юридичних осіб звернутися за адміністративною послугою;

- зручність - урахування інтересів та потреб утримувачів послуг у процесі організації надання адміністративних послуг;

- відкритість - безперешкодне одержання необхідної для отримання адміністративної послуги інформації, яка розміщується на інформаційних стендах в адміністративних органах, на їх веб-сайтах, друкується в офіційних виданнях та буклетах;

- професійність - належний рівень кваліфікації працівників адміністративного органу тощо [12].

Таким чином, зважаючи на вищевикладене, робимо висновок про те, що під послугою слід розуміти діяльність щодо надання однією стороною іншій певного блага, що має користь для цієї сторони, задовольняє їі потреби та може здійснюватися за ініціативою особи або ж на їі прохання. Проаналізовано визначення, закріплене у Законі України «Про електронні довірчі послуги», відповідно до якого «електронну послугу» слід розглядати як будь-яку послугу, що надається через інформаційно-телекомунікаційну систему. Також визначення електронних державних послуг знаходимо у Модельному законі про електронні державні послуги. Відповідно до нього, електронні державні послуги необхідно розуміти як державну послугу, що надається інформаційно-комунікаційною мережею з використанням інформаційних технологій. Аналізуючи поняття «електронні послуги», констатуємо, що його зміст тісно пов'язаний iз використанням інформаційнокомунікаційних технологій.

\section{Iimepamypa}

1. Тищенко Ю. Поняття «послуга»: в міжнародному та вітчизняному праві. Зовнішня торгівля: еконо міка, фінанси, право. 2018. № 4. С. 89-98.

2. Котлер Ф. Основы маркетинга, 4-е европейское издание. Москва : 000 «И.Д. Вильямс», 2010. $1200 \mathrm{c}$.

3. Цивільний кодекс України : Закон України від 16.01.2003 р. № 435-IV. Відомості Верховної Ради України. URL : https://zakon.rada.gov.ua/laws/ show/435-15\#Text

4. Про електронні довірчі послуги : Закон України від 05.10.2017 р. № 2155-VIII. Відомості Верховної Ради України. URL : https://zakon.rada.gov.ua/laws/ show/2155-19\#Text

5. Модельний закон про електронні державні послуги, який було прийнято на тридцять четвертому пленарному засіданні Міжпарламентської Асамблеї держав-учасників СНД (Постанова № 34-7 від 07.04.2010p.). URL : http://zakon4.rada.gov.ua/laws/ show/997_m99
6. Ємельяненко О. Традиційний та електронний уряд: концептуальні відмінності. URL: http://www. viche.info/journal/811/

7. Вишнякова С.С. Формирование сферы электронных услуг в России : дис. ... канд. экон. наук : 08.00.05 «Экономика и управление народным хозяйством». Москва, 2007. 187 с.

8. Битяк Ю.П, Богуцкий В.В., Гаращук В.Н. Административное право Украины : учебник для студ. высш. учеб. заведений юрид. спец. 2-е изд., перераб. и доп. Харьков : Право, 2003. 576 с.

9. Про адміністративні послуги : Закон України від 06. 09. 2012 р. № 5203-VI. Відомості Верховної Ради України. URL : https://zakon.rada.gov.ua/laws/ show/5203-17\#Text

10. Ішханян А.Р. Адміністративно-правові засади забезпечення надання електронних послуг : дис. ... канд. юрид. наук : 12.00.07 «Адміністративне право і процес; фінансове право; інформаційне право». Дніпро. 2020. 215 с.

11. Авер'янов В.Б. Адміністративна реформа i правова наука. Право України. 2002. № 3. С. 20-26.

12. Тищенкова I.О. Електронні послуги у діяльності публічної адміністрації: монографія. Дніпро: «Ліра ЛТД». 2017. 156 c.

\section{Анотація}

Харченко А. I., Уткіна М. С. Щодо електронних послуг в Україні: юридична природа, ознаки та принципи. - Стаття.

У статті охарактеризовано доктринальні та нормативні підходи до визначення таких понять, як «послуга» та «електронна послуга». У контексті реформ, що мають місце в Україні, необхідно наголосити на тому, що одним із напрямів діяльності Уряду є створення цифрової держави шляхом цифровізації послуг. Авторами виокремлено основні ознаки реалізації електронних послуг з урахуванням трактування цієї категорії. Зазначено, що, аналізуючи принципи надання електронних послуг, було визначено, що стаття 4 Закону України «Про адміністративні послуги» містить перелік загальних принципів надання електронних послуг. Цей закон варто розглядати у зв'язку із тим, що принципи надання електронних послуг становлять собою сукупність міжгалузевих принципів правової та управлінських сфер. До загальних належать принципи: 1) верховенства права, у тому числі законності та юридичної визначеності; 2) стабільності; 3) рівності перед законом; 4) відкритості тапрозорості; 5) оперативності та своєчасності; 6) доступності інформації про надання електронних послуг; 7) захищеності персональних даних; 8) раціональної мінімізації кількості документів та процедурних дій, що вимагаються для отримання електронних послуг; 9) неупередженості та справедливості; 10) доступності та зручності для суб'єктів звернень. Спеціальні принципи надання електронних послуг мають бути спрямовані на досягнення таких фундаментальних цілей, як підтримка балансу між інтересами держави й інтересами скаржників та підвищення довіри таких органів до діяльності адміністративних та державних органів влади. Автори зазначили, що до таких представники наукової спільноти відносять принципи: безперервності, результативності, професійності, відповідальності; єдності, підпорядкованості, територіально-галузевий та зонально-предметний; своєчасності, зручності, доступності, мовчазної згоди.

Ключові слова: електронні послуги, надання електронних послуг, послуга, принципи реалізації електронних послуг. 


\section{Summary}

Kharchenko A. L., Utkina M. S. On the electronic services in Ukraine: legal essence, features and principles. - Article.

The article describes doctrinal and normative approaches to the definition of such concepts as "service" and "electronic service". It was emphasized that in the context of the reforms taking place in Ukraine, it should be emphasized that one of the activities of the Government is the creation of a digital state through the digitalization of services. The authors highlighted the main features of the implementation of electronic services, taking into account the interpretation of this category. It is noted that, analyzing the principles of providing electronic services, it was determined that Article 4 of the Law of Ukraine "On Administrative Services" contains a list of general principles of providing electronic services. This law is considered due to the fact that the principles of electronic services are a set of intersectoral principles, in particular: legal and administrative spheres. The general principles include: 1 ) the principle of the rule of law, including legality and legal certainty; 2) stability; 3) equality before the law; 4) openness and transparency; 5) efficiency and timeliness; 6) availability of information on the provision of electronic services; 7) protection of personal data; 8) rational minimization of the number of documents and procedural actions required to obtain electronic services; 9) impartiality and justice; 10) accessibility and convenience for the subjects of appeals. In turn, special principles for the provision of electronic services should be aimed at achieving such fundamental goals as maintaining a balance between the interests of the state and the interests of complainants and increasing the confidence of such bodies in the activities of administrative and public authorities. The authors noted that such principles of the scientific community include the following: continuity, efficiency, professionalism, responsibility; unity, subordination, territorial-branch and zonal-subject principles; timeliness, convenience, accessibility, tacit consent.

Key words: electronic services, provision of electronic services, service, principles of realization of electronic services. 